\title{
23. PHYSICAL PROPERTIES SYNTHESIS
}

\author{
F. M. Cook, Independent, and \\ H. E. Cook, University of California, Riverside
}

\section{NATURAL GAMMA}

Of all physical property tests, natural gamma emission proved to be most significant in terms of detail and reliability. Drilling disturbance appeared to have less effect on recorded data. In many cases formations are distinguishable on the basis of natural gamma emission.

Natural gamma emissions range from a low of 749 counts per 75 seconds to a high of 3836 counts. Both these readings were recorded in sediments at Site 79.

Minerals and sediments which emitted recordable radiation are: pyroclastic ash, K-feldspar, montmorillonite, the potassic zeolites clinoptilolite and phillipsite, palagonite, and potassic mica.

The cyclic unit of the Clipperton Oceanic Formation yields counts from 813 to 2905 and records the highest average natural gamma emission of all the formations. This unit usually can be distinguished from underlying formations by higher readings. Also, the dark brown beds within the cyclic unit have higher natural gamma readings than the interbedded pale orange sediments. The average count in the cyclic unit is higher in the easterly sites; this may be due to a higher content of clay and pyroclastic materials.

The varicolored unit of the Clipperton Oceanic Formation yields readings from 774 to 3836 counts. The varicolored unit can be distinguished from the cyclic unit by its lower average readings.

The Marquesas Oceanic Formation yields counts from 785 to 1526. At some sites the Marquesas can be distinguished from overlying and underlying formations. The brown and gray units of the Marquesas are not distinguishable from one another on the basis of natural gamma emission, even though there are more clay minerals in the brown unit.

The Line Islands Oceanic Formation yields readings from 809 to 1398 counts and at some sites is distinguishable from overlying formations.

The San Blas Oceanic Formation yields counts from 775 to 1913 counts and can be differientiated from the overlying Clipperton Oceanic Formation and the underlying Line Islands Oceanic Formation. The average natural gamme readings in the San Blas increase to the east, due to the higher percentage of pyroclastic material in the sediments as Central America is

The uppermost few meters at each site recorded high natural gamma readings even though there is no obvious mineralogical reason.

\section{POROSITY}

Porosity ranges from 41 to 94 per cent. At most sites there is a definite downhole decrease in porosity which may be due to compaction, incipient cementation, or both. A good example of this decrease is seen in Hole 79 .

In some holes there is a definite correlation between porosity and lithology. Some stratigraphic intervals which contain large amounts of sand-sized radiolarians and foraminifera have higher porosities than beds dominantly of clay-sized calcareous nannofossils. The sand-sized biogenous constituents produce a grainsupported texture with both interparticle and intragrain porosity, whereas calcareous nannofossil oozes form mud-supported textures with only interparticle porosity.

Water injected into the sediments by drilling often makes the measuring of true porosity difficult. Rough seas also result in more drilling disturbances.

\section{SOUND VELOCITY}

Sound velocities range from 889 to $1995 \mathrm{~m} / \mathrm{sec}$. Probably as a result of compaction, velocities tend to increase downhole.

At most sites local differences in sound velocity are probably the result of water injected into the sediments by drilling. Drilling disturbance and water in sediments due to drilling often make reliable measurements impossible.

At Site 76, cores containing abundant phillipsitic mud give higher sound velocities than cores containing abundant foraminiferal-calcareous nannofossil ooze. 


\section{BULK DENSITY}

Bulk density measurements range between a high of $1.960 \mathrm{~g} / \mathrm{cc}$ and a low of $1.081 \mathrm{~g} / \mathrm{cc}$. Probably as a result of compaction the density usually increased downhole. Local density differences are common and in some cases can be attributed to changes in lithology, such as, a change to sediment with an abundance of radiolarians which form a more porous network. More often, drilling disturbance and water injected into the sediment during drilling are a serious obstacle to obtaining reliable data. Until the drilling disturbance problem can be solved, bulk density measurements cannot be considered wholly reliable.

\section{PENETROMETER}

Penetrometer measurements range from 0.1 centimeter to over 3 centimeters. Probably the highest reliable reading is 2.6 centimeters. Penetrability generally decreases downhole; this is most likely a result of compaction. Injection of water into the sediments during drilling produces very high penetrometer readings and many local variations. Drilling disturbance also often obliterates any systematic changes correlative with lithology, incipient cementation and compaction. As a result, penetrometer data is only crudely reliable. 